\title{
P064: Direct identification of vancomycin-resistant enterococci from selective enrichment broth by mass spectrometry
}

\author{
B-M Woo* , H Lee, S-I Joo, E-C Kim \\ From 2nd International Conference on Prevention and Infection Control (ICPIC 2013) \\ Geneva, Switzerland. 25-28 June 2013
}

\section{Introduction}

It is mandatory in South Korea that patients and carriers, from whom vancomycin-resistant enterococci (VRE) are detected, should be isolated from the other patients. The rapid detection of VRE is essential to prevent the dissemination of VRE. We determined the possibilities of direct identification of VRE from selective enrichment broth by mass spectrometry for the shortening of turn-around-time.

\section{Methods}

During the one-month period of VRE outbreak investigation, 50 rectal swabs were incubated into enterococcal broth containing $6 \mu \mathrm{g} / \mathrm{mL}$ of vancomycin at $37^{\circ} \mathrm{C}$ for 24 hours. For the rapid identification of VRE, total 50 pellets obtained after the centrifugation of one $\mathrm{mL}$ were applied on mass spectrometry. The results of the mass spectrometry were compared to those of standard culture using chromogenic agar for the detection of VRE.

\section{Results}

Among total 39 VRE isolated by standard culture, 32 were $E$. faecium only, and seven were mixed with both E. faecium and E. faecalis. By mass spectrometry total 33 VRE were identified of which 26 were $E$. faecium only and six were mixed with both E. faecium and E. faecalis, and one was E. faecalis only. Total 17 VRE-negative cases by mass spectrometry were four no-peak-found, four no-reliable, two Lactobacillus, four E. gallinarum, two E. avium, and one Pediococcus. Compared to chromogenic agar method, the sensitivity and specificity of mass spectrometry method were $84.6 \%$ and $100.0 \%$, respectively.

Department of Laboratory Medicine, Seoul National University Hospital, Seoul, Korea, Republic Of

\section{Conclusion}

Direct identification of VRE from selective enrichment broth by mass spectrometry may be helpful to shorten the turn-around-time. The mass spectrometry method can detect VRE one day earlier than the conventional method.

\section{Disclosure of interest}

None declared.

Published: 20 June 2013

doi:10.1186/2047-2994-2-S1-P64

Cite this article as: Woo et al:: P064: Direct identification of vancomycin-resistant enterococci from selective enrichment broth by mass spectrometry. Antimicrobial Resistance and Infection Control 2013 2(Suppl 1):P64.

\section{Submit your next manuscript to BioMed Central and take full advantage of: \\ - Convenient online submission \\ - Thorough peer review \\ - No space constraints or color figure charges \\ - Immediate publication on acceptance \\ - Inclusion in PubMed, CAS, Scopus and Google Scholar \\ - Research which is freely available for redistribution \\ Submit your manuscript at www.biomedcentral.com/submit}

